Check for updates

Cite this: RSC Adv., 2019, 9, 11451

Received 1st January 2019

Accepted 5th April 2019

DOI: 10.1039/c9ra00004f

rsc.li/rsc-advances

\section{Novel sulfonamidospirobifluorenes as fluorescent sensors for mercury(II) ion and glutathione $\uparrow$}

\author{
Komthep Silpcharu, ${ }^{a}$ Mongkol Sukwattanasinitt ${ }^{a b}$ and Paitoon Rashatasakhon (iD *ab
}

\section{Introduction}

Mercury is a highly toxic metal element. The World Health Organization (WHO $)^{1}$ has recommended reducing and eliminating the use of mercury in the environment because it causes several diseases such as Minamata disease ${ }^{2}$ and the risk of heart disease. ${ }^{3}$ However, mercury and its derivatives are used in medicinal, ${ }^{4}$ agricultural, ${ }^{5}$ and many other industrial applications. ${ }^{6}$ Hence, close monitoring of mercury and its ionic species that contaminate the environment is of great significance. Several techniques such as atomic absorption spectroscopy (AAS), ${ }^{7}$ atomic emission spectroscopy (AES), ${ }^{8}$ inductively coupled plasma-mass spectrometry (ICP-MS), ${ }^{9}$ and inductively coupled plasma-optical emission spectrometry (ICP-OES) ${ }^{10}$ are routinely used for the analysis of mercury. Even though these methods can provide high sensitivity, accuracy, and precision, they are not practical for real-time or on-site analysis. In addition, they require well-trained specialists and high instrument maintenance costs, which can be avoided using selective fluorescent recognition probes.

Recent examples of selective fluorescent probes for $\mathrm{Hg}$ (II) are the derivatives of triarylamine-triazine, ${ }^{11}$ rhodamine, ${ }^{12}$ bis-thiophene, ${ }^{\mathbf{1 3}}$ and coumarin. ${ }^{\mathbf{1 4}}$ During our research project on design and synthesis of selective fluorescent sensors, we became interested in spirobifluorene since it has high chemical and thermal stabilities with strong emission signal. ${ }^{15}$ Several derivatives of spirobifluorene are used as materials in optoelectronic devices

${ }^{a}$ Department of Chemistry, Faculty of Science, Chulalongkorn University, Bangkok 10330, Thailand

${ }^{b}$ Nanotec-CU Center of Excellence on Food and Agriculture, Department of Chemistry, Faculty of Science, Chulalongkorn University, Bangkok 10330, Thailand. E-mail: paitoon.r@chula.ac.th; Fax: +66 (2) 2187598; Tel: +66 (2) 2187633

$\dagger$ Electronic supplementary information (ESI) available. See DOI: 10.1039/c9ra00004f such as field-effect transistors (FET) ${ }^{\mathbf{1 6}}$ phototransistors, ${ }^{\mathbf{1 7}}$ solar cells, ${ }^{18}$ and organic light-emitting diodes. ${ }^{19}$ There are a few examples of spirobifluorenes used as fluorescent chemosensors for analytes such as nitric oxide, ${ }^{20} \mathrm{H}^{+},{ }^{21} \mathrm{Ag}(\mathrm{I}),{ }^{22}$ and $\mathrm{Hg}$ (II) ion. ${ }^{23}$ The sensing mechanism for $\mathrm{Hg}$ (II) is mostly involved specific hydrolysis reactions of thioacetals with $\mathrm{Hg}$ (II). ${ }^{24}$ Although these sensors exhibited excellent selectivity towards $\mathrm{Hg}(\mathrm{II})$, the irreversibility of hydrolysis reaction prevents further applications as a turn-on sensor for a secondary analyte.

In this work, we report our synthesis and application of two new derivatives of spirobifluorene named disulfonamidospirobifluorene (DSS) and tetrasulfonamidospirobifluorene (TSS) (Fig. 1). The sulfonamide groups are expected to function as<smiles>CS(=O)(=O)Nc1ccc(C#Cc2ccc3c(c2)C2(c4ccccc4-c4ccccc42)c2ccccc2-3)cc1</smiles>

Disulfonamidospirobifluorene (DSS)

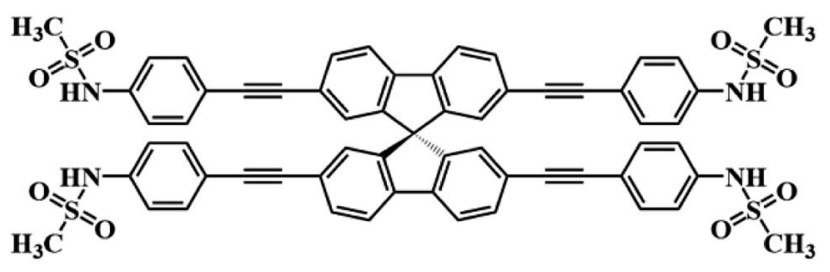

Tetrasulfonamidospirobifluorene (TSS)

Fig. 1 The structures of DSS and TSS 
specific binding sites for $\mathrm{Hg}(\mathrm{II}){ }^{25}$ This reversible complex formation may allow an application of this system as a turn-on fluorescent sensor for a secondary analyte such as cysteine and L-glutathione that can form a more stable complex with $\mathrm{Hg}(\mathrm{II}) \cdot{ }^{26} \mathrm{~L}^{-}$ Glutathione is a value-added ingredient in a variety of health supplements as it helps reduce oxidative stress, ${ }^{27}$ and symptoms of neurodegenerative diseases such as Alzheimer, ${ }^{28}$ and Parkinson's disease. ${ }^{29}$ The quantitative analysis of L-glutathione in health supplements by a competitive binding with $\mathrm{Hg}$ (II) in the DSS-Hg(II) complex will also be demonstrated.

\section{Experimental}

\subsection{Chemicals and materials}

All reagents and solvents were purchased from Merck (Germany), Sigma-Aldrich (USA), or Fluka (Switzerland). Unless stated otherwise, these chemicals were used without further purification. All column chromatography were operated using silica gel 60 (70-230 mesh) purchased from Merck. Water used in all spectroscopic experiments was deionized with a Milli-Q ${ }^{\circledR}$ reference water purification system (Merck) to a specific resistivity of $18.2 \mathrm{M} \Omega \mathrm{cm}$. The stock solutions of DSS and TSS were prepared in dimethyl sulfoxide (DMSO) at $1 \mathrm{mM}$ and diluted further to obtain expected concentrations. The stock solutions of metal ions in deionized water were prepared at $10 \mathrm{mM}$ using the following commercially available salts: $\mathrm{LiNO}_{3}, \mathrm{NaNO}_{3}$, $\mathrm{KNO}_{3}, \mathrm{AgNO}_{3}, \mathrm{Ca}\left(\mathrm{NO}_{3}\right)_{2}, \mathrm{Mg}\left(\mathrm{NO}_{3}\right)_{2}, \mathrm{Ba}\left(\mathrm{NO}_{3}\right)_{2}, \mathrm{Co}\left(\mathrm{NO}_{3}\right)_{2}$, $\mathrm{Cd}\left(\mathrm{NO}_{3}\right)_{2}, \mathrm{Zn}\left(\mathrm{NO}_{3}\right)_{2}, \mathrm{~Pb}\left(\mathrm{NO}_{3}\right)_{2}, \mathrm{Ni}\left(\mathrm{NO}_{3}\right)_{2}, \mathrm{Cu}\left(\mathrm{NO}_{3}\right)_{2}, \mathrm{Hg}(\mathrm{OAc})_{2}$, $\mathrm{Fe}(\mathrm{OAc})_{2}, \mathrm{Fe}\left(\mathrm{NO}_{3}\right)_{3}, \mathrm{Al}\left(\mathrm{NO}_{3}\right)_{3}, \mathrm{Bi}\left(\mathrm{NO}_{3}\right)_{3}, \mathrm{Cr}\left(\mathrm{NO}_{3}\right)_{3}$, and $\mathrm{AuCl}_{3}$. The $\mathrm{pH}$-controlled and buffer solutions in deionized water (10 $\mathrm{mM}$ ) were $\mathrm{NaCl} / \mathrm{HCl}$ buffer $(\mathrm{pH} 1-2)$, acetate buffer $(\mathrm{pH} 3-5)$, HEPES buffer ( $\mathrm{pH} 6-8)$, and glycine/NaOH buffer ( $\mathrm{pH} 9-10)$.

\subsection{Instruments}

${ }^{1} \mathrm{H}$ and ${ }^{13} \mathrm{C}$ NMR spectra were collected on a $400 \mathrm{MHz}$ NMR spectrometer which operated at $400 \mathrm{MHz}$ for ${ }^{1} \mathrm{H}$ and $100 \mathrm{MHz}$ for ${ }^{13} \mathrm{C}$ (Bruker Company). Mass spectra were recorded on a Microflex MALDI-TOF mass spectrometer (Bruker Daltonics). High-resolution mass spectra were obtained from a triple quadrupole GC/MS (Agilent Technologies). Elemental analysis was obtained from a CHNS/O analyzer (Flash 2000, Thermo Scientific). Absorption spectra were obtained from a UV-2250 UV-Vis Spectrophotometer (SHIMADZU, Japan) and emission spectra were obtained from a Carry Eclipse Fluorescence Spectrophotometer (Agilent Technologies). The absolute fluorescence quantum yields and lifetimes were determined using FLS980 Spectrometer (Edinburgh Instruments). The pH buffers were measured from an Ohaus $\mathrm{pH}$ meter. Amounts of $\mathrm{Hg}$ (II) ion in water samples were verified by an inductively coupled plasma-optical emission spectrometer (ICP-OES) (iCAP 6500, Thermo Scientific).

\subsection{Synthesis and characterizations}

2.3.1 Synthesis of 2,7-di(trimethylsilylethynyl)-9,9'-spirobifluorene (2a). A mixture of 2,7-dibromo-9,9'-spirobifluorene (1a, $0.50 \mathrm{~g}, 1.05 \mathrm{mmol}), \mathrm{Pd}\left(\mathrm{PPh}_{3}\right)_{2} \mathrm{Cl}_{2}(74.0 \mathrm{mg}, 0.11 \mathrm{mmol}), \mathrm{CuI}$
(40.0 mg, $0.21 \mathrm{mmol}), \mathrm{PPh}_{3}(55.6 \mathrm{mg}, 0.21 \mathrm{mmol})$, and ( $n$ $\mathrm{Bu})_{4} \mathrm{NBr}(34.0 \mathrm{mg}, 0.11 \mathrm{mmol})$ was dissolved in toluene $(5 \mathrm{~mL})$ and diisopropylamine $(5 \mathrm{~mL})$ under nitrogen atmosphere. After 15 minutes of stirring at ambient temperature, trimethylsilylacetylene $(0.62 \mathrm{~g}, 6.33 \mathrm{mmol})$ was added dropwise, and the reaction was heated at $100{ }^{\circ} \mathrm{C}$ for $24 \mathrm{~h}$. The crude was extracted with $\mathrm{CH}_{2} \mathrm{Cl}_{2}$ and $30 \% \mathrm{NH}_{4} \mathrm{Cl}$ solution. The organic phase was washed deionized water and brine, dried over anhydrous $\mathrm{Na}_{2} \mathrm{SO}_{4}$, filtered, and concentrated under reduced pressure. The crude residue was purified by silica gel column chromatography with hexane as the eluent. A light-yellow solid of $\mathbf{2 a}$ was obtained in $0.51 \mathrm{~g}(95 \%) .{ }^{1} \mathrm{H}-\mathrm{NMR}\left(400 \mathrm{MHz}, \mathrm{CDCl}_{3}\right) \delta \mathrm{ppm} 7.93(\mathrm{~d}$, $J=7.4 \mathrm{~Hz}, 1 \mathrm{H}), 7.83(\mathrm{~d}, J=7.8 \mathrm{~Hz}, 1 \mathrm{H}), 7.58(\mathrm{~d}, J=7.8 \mathrm{~Hz}, 1 \mathrm{H})$, $7.45(\mathrm{t}, J=7.3 \mathrm{~Hz}, 1 \mathrm{H}), 7.19(\mathrm{t}, J=7.3 \mathrm{~Hz}, 1 \mathrm{H}), 6.95(\mathrm{~s}, 1 \mathrm{H}), 6.79$ $(\mathrm{d}, J=7.4 \mathrm{~Hz}, 1 \mathrm{H}), 0.24(\mathrm{~s}, 9 \mathrm{H}),{ }^{13} \mathrm{C}-\mathrm{NMR}\left(100 \mathrm{MHz}, \mathrm{CDCl}_{3}\right)$ $\delta$ ppm 149.2, 147.7, 141.9, 141.4, 132.1, 128.2, 128.1, 127.8, $124.3,122.9,120.28,120.27,105.4,95.0,65.7,0.1$. MS (MALDITOF) calcd. for $\mathrm{C}_{35} \mathrm{H}_{32} \mathrm{Si}_{2}\left([\mathrm{M}]^{+}\right)$508.204, found 507.473.

2.3.2 Synthesis of $2,2^{\prime}, 7,7^{\prime}$-tetra(trimethylsilylethynyl)-9,9'spirobifluorene (2b). A mixture of 2,2',7,7'-tetrabromo-9,9'-spirobifluorene $(\mathbf{1 b}, 0.50 \mathrm{~g}, 0.79 \mathrm{mmol}), \mathrm{Pd}\left(\mathrm{PPh}_{3}\right)_{2} \mathrm{Cl}_{2}(55.5 \mathrm{mg}$, $0.08 \mathrm{mmol}$ ), $\mathrm{CuI}$ (30.1 mg, $0.16 \mathrm{mmol}$ ), and $\mathrm{PPh}_{3}$ (41.5 mg, 0.16 $\mathrm{mmol}$ ) was dissolved in toluene $(5 \mathrm{~mL})$ and diisopropylamine (5 $\mathrm{mL}$ ) under nitrogen atmosphere. After 15 minutes of stirring at ambient temperature, trimethylsilylacetylene $(0.47 \mathrm{~g}, 4.77$ $\mathrm{mmol}$ ) was added dropwise, and the reaction was heated at $100{ }^{\circ} \mathrm{C}$ for $24 \mathrm{~h}$. The crude was extracted with $\mathrm{CH}_{2} \mathrm{Cl}_{2}$ and $30 \%$ $\mathrm{NH}_{4} \mathrm{Cl}$ solution. The organic phase was washed deionized water and brine, dried over anhydrous $\mathrm{Na}_{2} \mathrm{SO}_{4}$, filtered, and concentrated under reduced pressure. The crude residue was purified by silica gel column chromatography with hexane as the eluent. A white solid of $\mathbf{2 b}$ was obtained in $0.52 \mathrm{~g}$ (94\%). ${ }^{1} \mathrm{H}-\mathrm{NMR}(400$ $\left.\mathrm{MHz}, \mathrm{CDCl}_{3}\right) \delta \mathrm{ppm} 7.77(\mathrm{~d}, J=7.9 \mathrm{~Hz}, 1 \mathrm{H}), 7.52$ (d, $J=7.9 \mathrm{~Hz}$, $1 \mathrm{H}), 6.81(\mathrm{~s}, 1 \mathrm{H}), 0.18(\mathrm{~s}, 9 \mathrm{H}),{ }^{13} \mathrm{C}-\mathrm{NMR}\left(100 \mathrm{MHz}, \mathrm{CDCl}_{3}\right) \delta \mathrm{ppm}$ 148.1, 141.4, 132.4, 127.8, 123.1, 120.4, 105.1, 95.3, 65.2, 0.0. MS (MALDI-TOF) calc. mass for $\mathrm{C}_{45} \mathrm{H}_{48} \mathrm{Si}_{4}\left([\mathrm{M}]^{+}\right)$700.283, found 699.728 .

2.3.3 Synthesis of 2,7-diethynyl-9,9'-spirobifluorene (3a). To a solution of $2 \mathrm{a}(0.50 \mathrm{~g}, 0.98 \mathrm{mmol})$ in $\mathrm{CH}_{2} \mathrm{Cl}_{2}(16 \mathrm{~mL})$ was added a solution of $\mathrm{NaOH}(0.39 \mathrm{~g}, 9.83 \mathrm{mmol})$ in $\mathrm{MeOH}(4 \mathrm{~mL})$ under nitrogen atmosphere. The reaction was stirred at room temperature for $15 \mathrm{~h}$. The reaction mixture was extracted with $\mathrm{CH}_{2} \mathrm{Cl}_{2}$ and deionized water. The organic phase was washed brine, dried over anhydrous $\mathrm{Na}_{2} \mathrm{SO}_{4}$, filtered, and concentrated under reduced pressure. The crude mixture was purified by silica gel column chromatography with $5 \% \mathrm{CH}_{2} \mathrm{Cl}_{2}$ in hexane as the eluent. A light-yellow solid of 3a was obtained in $0.36 \mathrm{~g}$ (100\%). ${ }^{1} \mathrm{H}-\mathrm{NMR}\left(400 \mathrm{MHz}, \mathrm{CDCl}_{3}\right) \delta \mathrm{ppm} 7.86(\mathrm{~d}, J=7.6 \mathrm{~Hz}$, $1 \mathrm{H}), 7.80(\mathrm{~d}, J=7.9 \mathrm{~Hz}, 1 \mathrm{H}), 7.53(\mathrm{~d}, J=7.9 \mathrm{~Hz}, 1 \mathrm{H}), 7.40(\mathrm{t}, J=$ $7.5 \mathrm{~Hz}, 1 \mathrm{H}), 7.14(\mathrm{t}, J=7.5 \mathrm{~Hz}, 1 \mathrm{H}), 6.89(\mathrm{~s}, 1 \mathrm{H}), 6.73(\mathrm{~d}, J=$ $7.6 \mathrm{~Hz}, 1 \mathrm{H}), 2.98(\mathrm{~s}, 1 \mathrm{H}),{ }^{13} \mathrm{C}-\mathrm{NMR}\left(100 \mathrm{MHz}, \mathrm{CDCl}_{3}\right) \delta \mathrm{ppm}$ 149.4, 147.6, 141.9, 141.6, 132.2, 128.2, 128.1, 128.0, 124.2, 121.9, 120.4, 120.3, 83.9, 77.9, 65.7. MS (MALDI-TOF) calc. mass for $\mathrm{C}_{29} \mathrm{H}_{16}\left([\mathrm{M}]^{+}\right)$364.125, found 363.221.

2.3.4 Synthesis of $2,2^{\prime}, 7,7^{\prime}$-tetraethynyl-9, $9^{\prime}$-spirobifluorene (3b). To a solution of $2 \mathbf{b}(0.46 \mathrm{~g}, 0.65 \mathrm{mmol})$ in $\mathrm{CH}_{2} \mathrm{Cl}_{2}(16 \mathrm{~mL})$ was added a solution of $\mathrm{NaOH}(0.26 \mathrm{~g}, 6.50 \mathrm{mmol})$ in $\mathrm{MeOH}(4$ 
$\mathrm{mL}$ ) under nitrogen atmosphere. The reaction was stirred at room temperature for $24 \mathrm{~h}$. The reaction mixture was extracted with $\mathrm{CH}_{2} \mathrm{Cl}_{2}$ and deionized water. The organic phase was washed brine, dried over anhydrous $\mathrm{Na}_{2} \mathrm{SO}_{4}$, filtered, and concentrated under reduced pressure. The crude residue was purified by silica gel column chromatography with $5 \% \mathrm{CH}_{2} \mathrm{Cl}_{2}$ in hexane as the eluent. A light-yellow solid of $\mathbf{3 b}$ was obtained in $0.27 \mathrm{~g}(100 \%) .{ }^{1} \mathrm{H}-\mathrm{NMR}\left(400 \mathrm{MHz}, \mathrm{CDCl}_{3}\right) \delta \mathrm{ppm} 7.79(\mathrm{~d}, J=$ $7.9 \mathrm{~Hz}, 1 \mathrm{H}), 7.54(\mathrm{~d}, J=7.9 \mathrm{~Hz}, 1 \mathrm{H}), 6.85(\mathrm{~s}, 1 \mathrm{H}), 3.01(\mathrm{~s}, 1 \mathrm{H})$, ${ }^{13} \mathrm{C}-\mathrm{NMR}\left(100 \mathrm{MHz}, \mathrm{CDCl}_{3}\right) \delta \mathrm{ppm}$ 148.0, 141.6, 132.6, 127.9, 122.2, 120.6, 83.7, 78.2, 65.2. MS (MALDI-TOF) calc. mass for $\mathrm{C}_{33} \mathrm{H}_{16}\left([\mathrm{M}]^{+}\right)$412.125, found 411.361.

2.3.5 Synthesis of $\mathrm{N}$-(4-iodophenyl)methanesulfonamide $\left(\mathrm{CH}_{3} \mathbf{S O}_{2} \mathbf{N H}-\mathrm{C}_{6} \mathrm{H}_{4}-\mathrm{I}\right)$. 4-Iodoaniline $(2.00 \mathrm{~g}, 9.13 \mathrm{mmol})$ was dissolved in $\mathrm{CH}_{2} \mathrm{Cl}_{2}(5 \mathrm{~mL})$ and pyridine $(0.81 \mathrm{~mL}, 10.04 \mathrm{mmol})$ at $0{ }^{\circ} \mathrm{C}$, and methanesulfonyl chloride $(0.88 \mathrm{~mL}, 11.41 \mathrm{mmol})$ was slowly added dropwise. The reaction was allowed to warm at room temperature and stirred for $15 \mathrm{~h}$. The reaction mixture was extracted with $\mathrm{CH}_{2} \mathrm{Cl}_{2}$ and $3 \mathrm{~N} \mathrm{NaOH}$ solution three times. The combined aqueous phase was acidified by concentrated $\mathrm{HCl}$, and a white solid of $\mathrm{CH}_{3} \mathrm{SO}_{2} \mathrm{NH}-\mathrm{C}_{6} \mathrm{H}_{4}$-I was filtered, washed with distilled water, and dried under vacuum. The product was obtained in $2.59 \mathrm{~g}(95 \%) .{ }^{1} \mathrm{H}-\mathrm{NMR}(400 \mathrm{MHz}$, acetone- $\left.\mathrm{D}_{6}\right) \delta \mathrm{ppm} 8.68(\mathrm{~s}, 1 \mathrm{H}), 7.69(\mathrm{~d}, J=8.6 \mathrm{~Hz}, 2 \mathrm{H}), 7.16(\mathrm{~d}, J$ $=8.6 \mathrm{~Hz}, 2 \mathrm{H}), 3.02(\mathrm{~s}, 3 \mathrm{H}),{ }^{13} \mathrm{C}-\mathrm{NMR}\left(100 \mathrm{MHz}\right.$, acetone- $\left.\mathrm{D}_{6}\right)$ $\delta \mathrm{ppm}$ 139.3, 139.1, 122.9, 87.9, 39.5. HRMS (ESI) calc. mass for $\mathrm{C}_{7} \mathrm{H}_{7} \mathrm{INO}_{2} \mathrm{~S}^{-}\left([\mathrm{M}-\mathrm{H}]^{-}\right)$295.92423, found 295.94424.

2.3.6 Synthesis of disulfonamidospirobifluorene (DSS). A mixture of $\mathrm{CH}_{3} \mathrm{SO}_{2} \mathrm{NH}-\mathrm{C}_{6} \mathrm{H}_{4}-\mathrm{I}(0.73 \mathrm{~g}, 2.47 \mathrm{mmol}), \mathrm{Pd}\left(\mathrm{PPh}_{3}\right)_{4}$ (95.1 mg, $0.08 \mathrm{mmol})$, CuI (15.6 mg, $0.08 \mathrm{mmol}$ ), and $\mathrm{PPh}_{3}$ (10.8 mg, $0.04 \mathrm{mmol}$ ) were dissolved in toluene $(4 \mathrm{~mL})$ and diisopropylamine $(5 \mathrm{~mL})$ under nitrogen atmosphere. After 15 minutes of stirring at room temperature, $3 \mathrm{a}(0.15 \mathrm{~g}, 0.41 \mathrm{mmol})$ that was dissolved in DMSO $(1 \mathrm{~mL})$ was dropped slowly via a syringe over a period of 5 minutes, and the reaction was heated at $50{ }^{\circ} \mathrm{C}$ for $24 \mathrm{~h}$. The crude was extracted with $\mathrm{CH}_{2} \mathrm{Cl}_{2}$ and $30 \%$ $\mathrm{w} / \mathrm{v} \mathrm{NH}_{4} \mathrm{Cl}$. The organic phase was washed deionized water and brine, dried over anhydrous $\mathrm{Na}_{2} \mathrm{SO}_{4}$, filtered, and concentrated under reduced pressure. The crude residue was purified by silica gel column chromatography with $60 \%$ ethyl acetate in hexane as the eluent. A light-brown solid of DSS was obtained in $0.20 \mathrm{~g}$ (69\%). ${ }^{1} \mathrm{H}-\mathrm{NMR}\left(400 \mathrm{MHz}, \mathrm{CDCl}_{3}\right) \delta \mathrm{ppm} 7.88(\mathrm{~d}, J=7.6 \mathrm{~Hz}, 1 \mathrm{H})$, $7.82(\mathrm{~d}, J=7.9 \mathrm{~Hz}, 1 \mathrm{H}), 7.55(\mathrm{~d}, J=8.0 \mathrm{~Hz}, 1 \mathrm{H}), 7.41(\mathrm{t}, J=7.5 \mathrm{~Hz}$, $1 \mathrm{H}), 7.38(\mathrm{~d}, J=8.3 \mathrm{~Hz}, 2 \mathrm{H}), 7.33(\mathrm{~s}, 1 \mathrm{H}), 7.16(\mathrm{~d}, J=8.0 \mathrm{~Hz}, 2 \mathrm{H})$, $7.15(\mathrm{t}, J=7.4 \mathrm{~Hz}, 1 \mathrm{H}), 6.92(\mathrm{~s}, 1 \mathrm{H}), 6.77(\mathrm{~d}, J=7.5 \mathrm{~Hz}, 1 \mathrm{H}), 3.00$ $(\mathrm{s}, 3 \mathrm{H}),{ }^{13} \mathrm{C}-\mathrm{NMR}\left(100 \mathrm{MHz}, \mathrm{CDCl}_{3}\right) \delta \mathrm{ppm} 149.4,147.8,141.9$, $141.3,136.8,133.0,131.7,128.23,128.17,127.4,124.3,122.8$, 120.4, 120.3, 120.03, 119.96, 90.2, 89.4, 65.8, 39.7. MS (MALDITOF) calc. mass for $\mathrm{C}_{43} \mathrm{H}_{30} \mathrm{~N}_{2} \mathrm{O}_{4} \mathrm{~S}_{2}\left([\mathrm{M}]^{+}\right) 702.165$, found 701.918. Elemental analysis (\%) calc. for $\mathrm{C}_{43} \mathrm{H}_{30} \mathrm{~N}_{2} \mathrm{O}_{4} \mathrm{~S}_{2}$ : C, 73.48; H, 4.30; N, 3.99. Found: C, 73.26; H, 4.48; N, 3.75.

2.3.7 Synthesis of tetrasulfonamidospirobifluorene (TSS). A mixture of $\mathrm{CH}_{3} \mathrm{SO}_{2} \mathrm{NH}-\mathrm{C}_{6} \mathrm{H}_{4}-\mathrm{I}(0.86 \mathrm{~g}, 2.91 \mathrm{mmol}), \mathrm{Pd}\left(\mathrm{PPh}_{3}\right)_{4}$ (56.0 mg, $0.05 \mathrm{mmol}$ ), CuI (9.2 $\mathrm{mg}, 0.05 \mathrm{mmol}$ ), and $\mathrm{PPh}_{3}$ (12.7 $\mathrm{mg}, 0.05 \mathrm{mmol}$ ) were dissolved in toluene $(4 \mathrm{~mL})$, and diisopropylamine $(4 \mathrm{~mL})$ under nitrogen atmosphere. After 15 minutes of stirring at room temperature, $3 \mathbf{b}(0.10 \mathrm{~g}, 0.24 \mathrm{mmol})$ that was dissolved in DMSO (2 mL) was dropped slowly via a syringe over a period of 5 minutes. The reaction was heated at $50{ }^{\circ} \mathrm{C}$ for $48 \mathrm{~h}$, allowed to cool to room temperature, and extracted with $\mathrm{CH}_{2} \mathrm{Cl}_{2}$ and $30 \% \mathrm{w} / \mathrm{v} \mathrm{NH}_{4} \mathrm{Cl}$. The organic phase was washed with deionized water and brine, dried over anhydrous $\mathrm{Na}_{2} \mathrm{SO}_{4}$, filtered, and concentrated under reduced pressure. The crude mixture was purified by silica gel column chromatography with $80 \%$ ethyl acetate in hexane as the eluent. A light-brown solid of TSS was obtained in $0.04 \mathrm{~g}(15 \%) .{ }^{1} \mathrm{H}-$ NMR (400 MHz, acetone- $\left.\mathrm{D}_{6}\right) \delta \mathrm{ppm} 8.77(\mathrm{~s}, 1 \mathrm{H}), 8.09(\mathrm{~d}, J=$ $7.9 \mathrm{~Hz}, 1 \mathrm{H}), 7.60(\mathrm{~d}, J=7.9 \mathrm{~Hz}, 1 \mathrm{H}), 7.42(\mathrm{~d}, J=8.7 \mathrm{~Hz}, 2 \mathrm{H}), 7.28$ $(\mathrm{d}, J=8.7 \mathrm{~Hz}, 2 \mathrm{H}), 6.92(\mathrm{~s}, 1 \mathrm{H}), 3.00(\mathrm{~s}, 3 \mathrm{H}),{ }^{13} \mathrm{C}-\mathrm{NMR}(100 \mathrm{MHz}$, acetone- $\left.\mathrm{D}_{6}\right) \delta$ ppm 149.3, 142.2, 139.8, 133.5, 132.7, 127.5, 124.0, 122.1, 120.3, 119.2, 90.8, 89.8, 66.1, 39.8. MS (MALDI-TOF) calc. mass for $\mathrm{C}_{61} \mathrm{H}_{44} \mathrm{~N}_{4} \mathrm{O}_{8} \mathrm{~S}_{4}\left([\mathrm{M}]^{+}\right)$1088.204, found 1089.066. Elemental analysis (\%) calc. for $\mathrm{C}_{61} \mathrm{H}_{44} \mathrm{~N}_{4} \mathrm{O}_{8} \mathrm{~S}_{4}$ : C, 67.26; H, 4.07; N, 5.14. Found: C, 67.01; H, 4.30; N, 4.99.

\subsection{Quantum yield determinations}

The excitation wavelengths for DSS and TSS were set at $360 \mathrm{~nm}$ and the integrated area of the emission signals was set from 370 to $600 \mathrm{~nm}$. The signal rate on the instrument was set to $1 \times 10^{6}$ counts per second. The emission signals were detected on the integrating sphere and analyzed by F980 software (Edinburgh instrument).

\section{Results and discussion}

\subsection{Synthesis}

The synthesis of DSS and TSS (Scheme 1) began with a Sonogashira coupling between the commercially available brominated spirobifluorenes $(\mathbf{1} \mathbf{a}, \mathbf{b})$. Both substrates were effectively coupled with trimethylsilylacetylene in excellent yields. After a treatment with $\mathrm{NaOH}$ in $\mathrm{MeOH}$ and $\mathrm{CH}_{2} \mathrm{Cl}_{2}$, the corresponding terminal alkyne $\mathbf{3 a}$ and $\mathbf{3} \mathbf{b}$ were produced in quantitative yields. In the last step, $\mathbf{3 a}$ and $\mathbf{3 b}$ were reacted with $N$-(4-iodophenyl)methanesulfonamide $\left(\mathrm{CH}_{3} \mathrm{SO}_{2} \mathrm{NH}-\mathrm{C}_{6} \mathrm{H}_{4}-\mathrm{I}\right)$, which was prepared from 4-iodoaniline, to afford DSS and TSS in 69 and 15\% yields, respectively. It should be noted that the polymerization of $3 \mathbf{b}$ was responsible for a diminished yield of TSS as a dark brown spot was observed on the TLC baseline, while the formation of mono-, di-, and tri-substituted products were not observed.

\subsection{Photophysical properties}

The UV-Vis absorption and emission spectra of DSS and TSS in DMSO are shown in Fig. 2, and the photophysical properties are summarized in Table 1. The maximum wavelengths of absorption and emission for both compounds were quite similar due to a relatively identical $\pi$-conjugated system between phenylacetylene and spirobifluorene units. However, the molar extinction coefficient for TSS is significantly higher than that of DSS because of a higher number of phenylacetylene units. The fluorescence quantum yield of DSS is significantly higher than that of TSS while their fluorescent lifetimes are relatively similar. These data suggest that the excited state of TSS has a higher tendency to lose energy via non-radiative proton transfer with DMSO. 


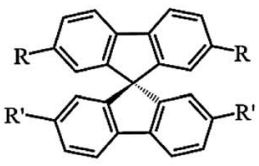

1a: $\mathrm{R}=\mathrm{Br} ; \mathrm{R}^{\prime}=\mathrm{H}$

$1 \mathbf{b}: \mathrm{R}=\mathrm{Br} ; \mathrm{R}^{\prime}=\mathrm{Br}$

DSS from 3a (69\%)

TSS from $3 \mathbf{b}(15 \%)$

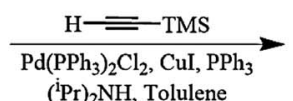

$\left({ }^{\mathrm{i}} \mathrm{Pr}\right)_{2} \mathrm{NH}$, Tolulene

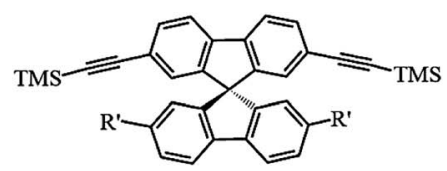

2a: $\mathrm{R}^{\prime}=\mathrm{H}(95 \%)$

2b: $\mathrm{R}^{\prime}=-\xi \xi=$ TMS $(94 \%)$

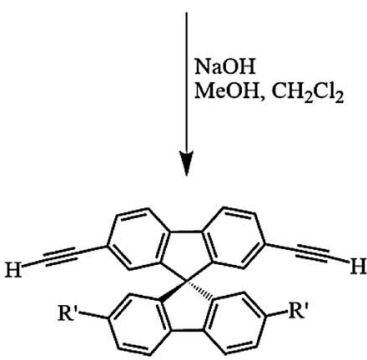

3a: $\mathrm{R}^{\prime}=\mathrm{H}(100 \%)$

3b: $\mathrm{R}^{\prime}=-\xi \stackrel{\xi}{=} \mathrm{H}(100 \%)$

Scheme 1 Synthesis of the DSS and TSS.

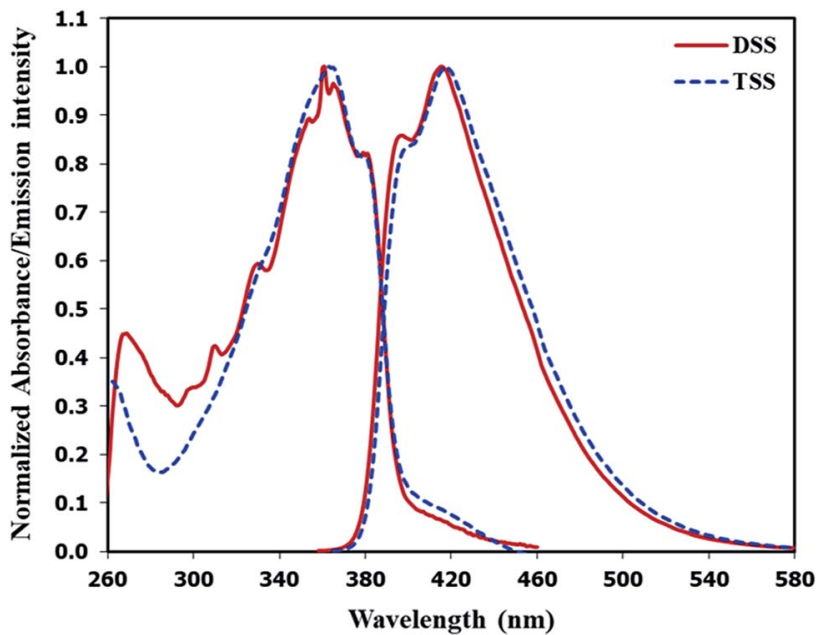

Fig. 2 Normalized absorption and emission spectra of DSS and TSS in DMSO.

Table 1 Photophysical properties of DSS and TSS in DMSO

\begin{tabular}{llllll}
\hline Cmpd. & $\lambda_{\mathrm{abs}}(\mathrm{nm})$ & $\varepsilon\left(\mathrm{M}^{-1} \mathrm{~cm}^{-1}\right)$ & $\lambda_{\mathrm{em}}{ }^{a}(\mathrm{~nm})$ & $\Phi_{\mathrm{f}}{ }^{b}$ & $\tau^{c}(\mathrm{~ns})$ \\
\hline DSS & 361 & 26900 & 415 & 0.85 & 0.74 \\
TSS & 363 & 45400 & 417 & 0.55 & 0.80
\end{tabular}

${ }^{a}$ Excited at $\lambda_{\text {abs. }}{ }^{b}$ Absolute fluorescence quantum yield. ${ }^{c}$ Fluorescence lifetime.

\subsection{Solvent effect}

The fluorescence spectra of DSS and TSS in various solvents are shown in Fig. S1. $\dagger$ The data suggested that DSS and TSS have good solubility in most solvents. In non-polar solvent like hexane and highly polar solvent like DMSO and water, a bathochromic shift and lower emission signals were detected. This could be rationale by their poor solubility in hexane and water or stabilization of excited states by DMSO. Even though the fluorescent signals are lower in DMSO compared to ethanol, methanol or acetonitrile, its high boiling point and low evaporating rate make it a suitable solvent for stock solution. Since the $\mathrm{Hg}(\mathrm{II})$ sensing applications are usually conducted in aqueous media, the optimal ratio of water and DMSO was investigated, and the results are shown in Fig. S2. $\dagger$ The fluorescence intensities of both compounds decreased upon the increment of water content, probably due to some aggregation or precipitation. Based on their emission intensity and UV-Vis absorbance in Fig. S3, $\uparrow 50 \%$ and $30 \%$ seem like thresholds of water contents for further sensing studies of DSS and TSS, respectively.

\subsection{Metal ion sensing studies}

The selectivity screening was performed using stock solutions of DSS and TSS in DMSO diluted with HEPES buffer pH 7.0 and DMSO to achieve $10 \mu \mathrm{M}$ solution of sensors. These solutions were treated with 10 mole equivalents of 20 metal ions including $\mathrm{Li}(\mathrm{I}), \mathrm{Na}(\mathrm{I}), \mathrm{K}(\mathrm{I}), \mathrm{Ag}(\mathrm{I}), \mathrm{Ca}(\mathrm{II}), \mathrm{Mg}(\mathrm{II}), \mathrm{Ba}(\mathrm{II}), \mathrm{Co}(\mathrm{II})$, $\mathrm{Cd}(\mathrm{II}), \mathrm{Zn}$ (II), Pb(II), Ni(II), Cu(II), Hg(II), Fe(II), Fe(III), Al(III), $\mathrm{Bi}(\mathrm{III}), \mathrm{Cr}(\mathrm{III})$, and $\mathrm{Au}(\mathrm{III})$. The results in Fig. 3 show that DSS and TSS have excellent selectivity towards $\mathrm{Hg}$ (II) ion with a 45and 107-folds fluorescence quenching, respectively. The quantitative determination of $\mathrm{Hg}$ (II) was studied by fluorescence titration experiments. Linear plots were obtained in the $\mathrm{Hg}$ (II) concentrations between 0 to $0.1 \mu \mathrm{M}$ for DSS and 0 to $1 \mu \mathrm{M}$ for TSS (Fig. 4). The detection limits for $\mathrm{Hg}$ (II) at three-time noise were $10.4 \mathrm{nM}$ for DSS and $103.8 \mathrm{nM}$ for TSS. In addition, the interfering effect of foreign ions at $1 \mathrm{mM}(10$ times concentration of $\mathrm{Hg}$ (II)) was studied, and the results indicated that only $\mathrm{Fe}$ (II) can interfere the detection of $\mathrm{Hg}$ (II) (Fig. S4 $\dagger$ ). A competitive absorption mechanism was proposed since the UV-Vis spectra of Fe(II) completely overlapped with those of DSS and TSS (Fig. S5†). 

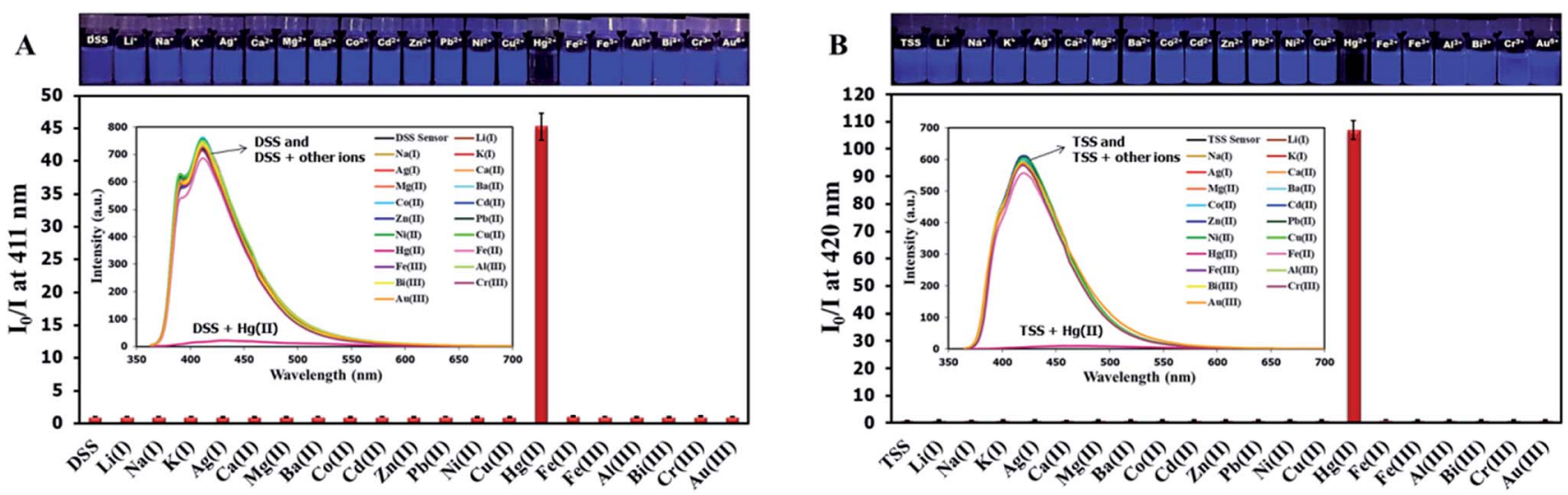

Fig. 3 (A) Fluorescence responses of DSS $(10 \mu \mathrm{M})$ and (B) TSS $(10 \mu \mathrm{M})$ towards various metal ions $(100 \mu \mathrm{M})$.
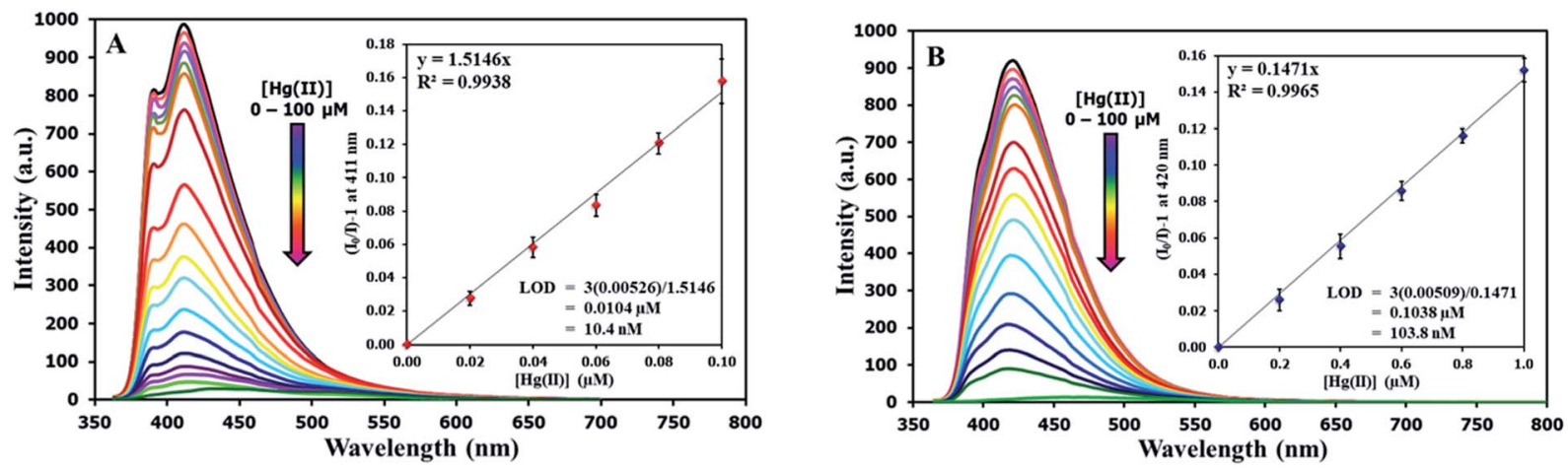

Fig. 4 (A) Fluorescence responses of DSS $(10 \mu \mathrm{M})$ and (B) TSS $(10 \mu \mathrm{M})$ towards various concentrations of $\mathrm{Hg}(\mathrm{N})$.

\subsection{Effect of $\mathrm{pH}$}

Because DSS and TSS contain acidic-NH groups, it is important to study the effect of $\mathrm{pH}$ on their fluorescence signals and sensitivity towards $\mathrm{Hg}$ (II). Data in Fig. S6† indicated that the original fluorescence signals of DSS and TSS were steady under acidic to neutral $\mathrm{pH}$ ranges and gradually decreased in basic media. Upon addition of $\mathrm{Hg}$ (II), the signals were decreased at all pHs, however, the quenching effect was most pronounced between 6.5 to 7.5. Therefore, the optimal working $\mathrm{pH}$ was selected at 7.0. The $\mathrm{pH}$ effect also provides a hint on the sensing mechanism which will be explained later.

\subsection{Mechanism of sensing}

Since the emission signals of both DSS and TSS were lowered under basic pHs, it is likely that the sensing mechanism may involve the deprotonation. For the investigation of sensing mechanism, we first examined the ${ }^{1} \mathrm{H}$-NMR spectra of DSS in D6-DMSO before and after the addition of 1 equivalent of $\mathrm{Hg}$ (II), and found that the $-\mathrm{NH}$ signal disappeared and the signal for the nearby aromatic - $\mathrm{CH}$ shifted slightly downfield when $\mathrm{Hg}$ (II) was added (Fig. 5). We postulated that the coordination between the sulfonamide and $\mathrm{Hg}$ (II) could promote a deprotonation of the - NH group at neutral pH. The addition of EDTA to DSS$\mathrm{Hg}$ (II) and TSS-Hg(II) mixtures could restore the emission signals, which were completely recovered when the $\mathrm{Hg}$ (II)-EDTA stoichiometry reached 1:1 (Fig. S7†). In addition, lower absorbance and shifted baseline were observed in the UV-Vis spectra of DSS-Hg(II), along with a Tyndall effect (Fig. S8†). These results confirmed that the sensing mechanism involved a coordination between the sulfonamide group and $\mathrm{Hg}$ (II) that lead to an aggregation of such complex presumably via the faceto-face stacking of the spirobifluorene cores. ${ }^{30}$ This static binding quenching mechanism was ultimately proven by SternVolmer plots at different temperatures (Fig. S9†). The decreases in quenching efficiencies (lower $K_{\mathrm{SV}}$ ) at the higher temperature suggested that the formation of $\mathrm{Hg}$ (II) complex is responsible for signals quenching.

\subsection{Quantitative analysis of $\mathrm{Hg}$ (II) in water samples}

To demonstrate the use of DSS and TSS as sensors for $\mathrm{Hg}$ (II) in water, we selected 3 sources of water samples, spiked them with $\mathrm{Hg}$ (II), and analyzed the amount of $\mathrm{Hg}$ (II) using traditional ICP-OES technique and our sensors. The analysis results in Table 2 showed a good recovery of $\mathrm{Hg}$ (II) in each sample, while the statistical results in Table $\mathrm{S} 1 \dagger$ indicated an insignificant difference between data from ICP-OES and our method ( $p$-value $>0.05)$.

\subsection{Detection of $\mathrm{L}$-glutathione}

There have been several reports on specific binding between $\mathrm{Hg}$ (II) and L-glutathione, which is a biologically important 


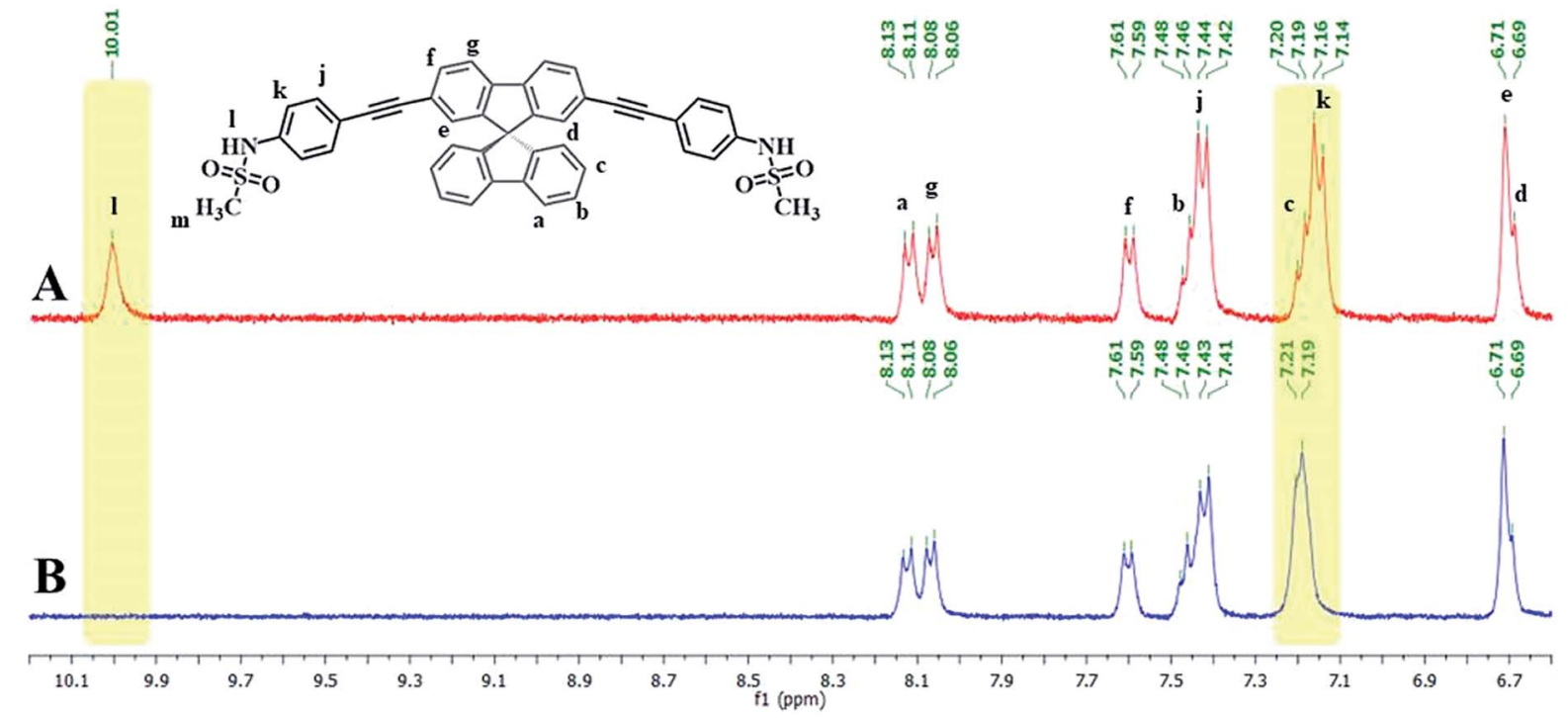

Fig. 5 (A) ${ }^{1} \mathrm{H}-\mathrm{NMR}$ spectra of DSS and (B) DSS $+\mathrm{Hg}(\mathrm{OAC})_{2}(1.0$ eq.) in D6-DMSO.

Table 2 Analytical results of $\mathrm{Hg}(॥)$ in water samples $(n=3)$

\begin{tabular}{|c|c|c|c|c|c|c|c|}
\hline Samples & Hg(II) added (ppm) & $\mathrm{Hg}$ (II) found (ppm) & Recovery (\%) & $\mathrm{Hg}$ (II) found (ppm) & Recovery (\%) & $\mathrm{Hg}$ (II) found (ppm) & Recovery (\%) \\
\hline & 1.0 & $1.118 \pm 0.022$ & 112 & $1.041 \pm 0.048$ & 104 & $1.101 \pm 0.085$ & 110 \\
\hline \multirow[t]{2}{*}{ Tap water } & 0.5 & $0.513 \pm 0.030$ & 103 & $0.506 \pm 0.045$ & 101 & $0.512 \pm 0.067$ & 102 \\
\hline & 1.0 & $1.185 \pm 0.036$ & 118 & $1.055 \pm 0.058$ & 105 & $1.116 \pm 0.099$ & 112 \\
\hline
\end{tabular}

antioxidant and a major component in food supplements and cosmetics. In our study, we tested the ability of L-glutathione and other food ingredients to restore the fluorescence signal of
DSS, and found that the DSS-Hg(II) complex can exhibit a selective fluorescence turn-on by L-glutathione (Fig. 6, S10 $\dagger$ ). Ascorbic acid and its sodium salt, which are known to

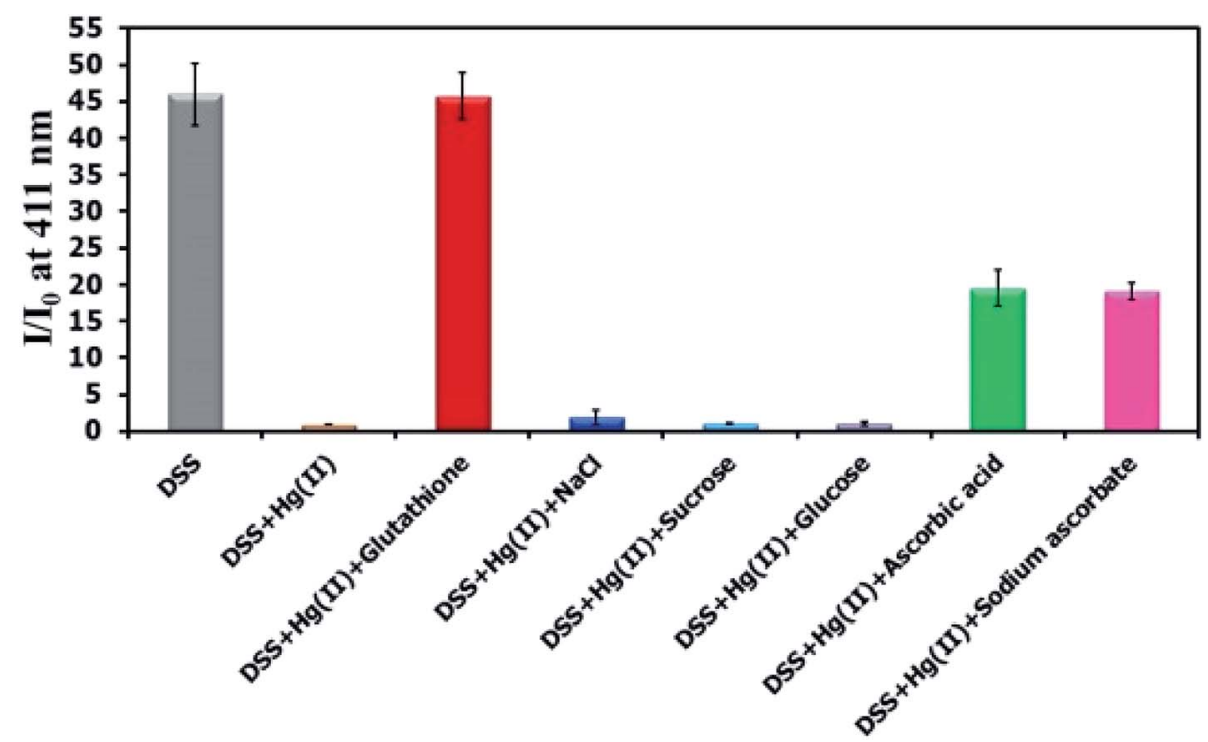

Fig. 6 Fluorescence response of DSS $(10 \mu \mathrm{M})$ with $\mathrm{Hg}(॥)(100 \mu \mathrm{M})$ and other beverage ingredients $(300 \mu \mathrm{M})$. 


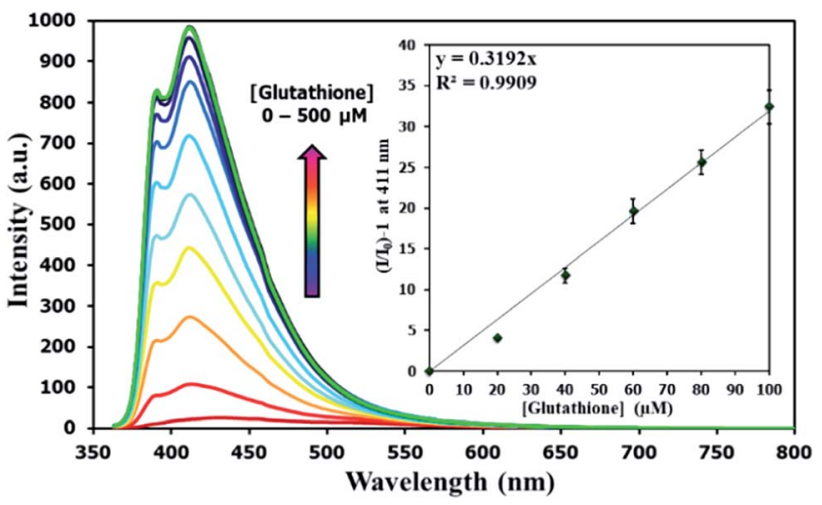

Fig. 7 Fluorescence responses of DSS $(10 \mu \mathrm{M})$ with $\mathrm{Hg}(I)(100 \mu \mathrm{M})$ upon addition of L-glutathione.

Table 3 Analytical results of L-glutathione in three commercial beverages $(n=3)$

\begin{tabular}{llll}
\hline & & \multicolumn{2}{l}{ Analyzed by DSS-Hg(II) } \\
\cline { 3 - 4 } Samples & Labeled content (\%) & Found (\%) & Recovery (\%) \\
\hline 1 & 0.05 & $0.0512 \pm 0.0042$ & 102 \\
2 & 0.10 & $0.1102 \pm 0.0090$ & 110 \\
3 & 0.30 & $0.2946 \pm 0.0128$ & 98
\end{tabular}

coordinate with $\mathrm{Hg}$ (II), can also restore the fluorescence signal, albeit in lower levels. However, the amount of ascorbic acid in most samples is usually 10 -folds lower than L-glutathione. Quantitative analysis revealed a detection limit of about $0.6 \mu \mathrm{M}$ or approximately $200 \mathrm{ppb}$ of L-glutathione (Fig. 7). The applications of DSS for analyses of L-glutathione on three supplement beverages showed good agreements between the labeled and experimental contents (Table 3).

\section{Conclusion}

In summary, we successfully synthesized two derivatives of spirobifluorene containing methanesulfonamide groups. Both compounds showed a selective fluorescence quenching by $\mathrm{Hg}$ (II) via complexation and aggregation-caused quenching. The detection limits for $\mathrm{Hg}$ (II) were $10.4 \mathrm{nM}$ and $103.8 \mathrm{nM}$ for the derivatives bearing two and four sulfonamide groups, respectively. One of these mercury complexes was used as a selective turn-on sensor for L-glutathione with a detection limit of 0.6 $\mu \mathrm{M}$. A satisfactory quantitative analysis of $\mathrm{L}$-glutathione in three supplement drinks was also demonstrated.

\section{Conflicts of interest}

There are no conflicts to declare.

\section{Acknowledgements}

KS thanks the Graduate School, Chulalongkorn University for the $72^{\text {nd }}$ Anniversary of His Majesty King Bhumibol Adulyadej and the $90^{\text {th }}$ Anniversary of Chulalongkorn University Funds (Ratchadaphiseksomphot Endowment Fund). This work is supported by the Nanotechnology Center (NANOTEC), NSTDA, Ministry of Science and Technology, Thailand, through its program on Research Network NANOTEC (RNN), and the Grant for International Research Integration: Chula Research Scholar. We also thank Prof. Kanet Wongravee for his help on statistical analysis, Prof. Vinich Promarak and Mr Phatananawee Nalaoh of VISTEC for their helps on fluorescence quantum yield and lifetime measurements, and the Sci. Spec. Company Limited for the ICP-OES experiments.

\section{References}

1 WHO, Exposure to Mercury: A Major Public Health Concern, Preventing Disease through Healthy Environments, World Health Organization, Geneva, 2007, http://www.who.int/ phe/news/Mercury-flyer.pdf, (accessed July, 2018).

2 N. Hachiya, J. Jpn. Med. Assoc., 2006, 49, 112-118.

3 T. J. Larsen, M. E. Jørgensen, C. V. L. Larsen, I. K. DahlPetersen, P. F. Rønn, P. Bjerregaard and S. Byberg, Environ. Res., 2018, 164, 310-315.

4 J. Aaseth, B. Hilt and G. Bjørklund, Environ. Res., 2018, 164, 65-69.

5 Y. Zhou, M. Aamir, K. Liu, F. Yang and W. Liu, Environ. Pollut., 2018, 240, 116-124.

6 (a) Y. Wang, T. Tian, W. Zang and X. Jian, Procedia Environ. Sci., 2016, 31, 432-439; (b) S. Kim, Y. Eom and T. G. Lee, J. Ind. Eng. Chem., 2018, 61, 288-294.

7 T. Lech, Forensic Sci. Int., 2014, 237, e1-e5.

8 R. Shekhar, Talanta, 2012, 93, 32-36.

9 S. Zhu, B. Chen, M. He, T. Huang and B. Hu, Talanta, 2017, 171, 213-219.

10 A. E. Fathabad, N. Shariatifar, M. Moazzen, S. Nazmara, Y. Fakhri, M. Alimohammadi, A. Azari and A. M. Khaneghah, Food Chem. Toxicol., 2018, 115, 436-446.

$11 \mathrm{H}$. Zhang, Y. Qu, Y. Gao, J. Hua, J. Li and B. Li, Tetrahedron Lett., 2013, 54, 909-912.

12 (a) Y. Yan, G. Ding and H. Xu, J. Ind. Eng. Chem., 2015, 25, 7377; (b) Y. Jiao, L. Zhang and P. Zhou, Talanta, 2016, 150, 1419.

13 Q. Niu, X. Wu, T. Li, Y. Cui, S. Zhang and X. Li, Spectrochim. Acta, Part A, 2016, 163, 45-48.

14 J. Chen, W. Liu, Y. Wang, H. Zhang, J. Wu, H. Xu, W. Ju and P. Wang, Tetrahedron Lett., 2013, 54, 6447-6449.

15 T. P. I. Saragi, T. Spehr, A. Siebert, T. Fuhrmann-Lieker and J. Salbeck, Chem. Rev., 2007, 107, 1011-1065.

16 C. Isenberg, T. Reichert and T. P. I. Saragi, Synth. Met., 2015, 208, 29-34.

17 T. P. I. Saragi, K. Onken, I. Suske, T. Fuhrmann-Lieker and J. Salbeck, Opt. Mater., 2007, 29, 1332-1337.

18 M.-D. Zhang, D.-X. Zhao, L. Chen, N. Pan, C.-Y. Huang, H. Cao and M.-D. Chen, Sol. Energy Mater. Sol. Cells, 2018, 176, 318-323.

19 P. Wu, J. Zhu, Z. Zhang, D. Dou, H. Wang, B. Wei and Z. Wang, Dyes Pigm., 2018, 156, 185-191. 
20 L.-Y. Lin, X.-Y. Lin, F. Lin and K.-T. Wong, Org. Lett., 2011, 13, 2216-2219.

21 Z. Han, J. Tan, T. Wei, Y. Zhang, H. Xiao, L. Xu and B. He, Sens. Actuators, B, 2018, 255, 2290-2297.

22 H. Xiao, Y. Zhang, W. Zhang, S. Li and R. Xu, Sens. Actuators, $B, 2016,233,469-475$.

23 B. Yang and W. Wu, Anal. Methods, 2013, 5, 4716-4722.

24 (a) H. Xiao, Y. Zhang, S. Li, W. Zhang, Z. Han, J. Tan, S. Zhang and J. Du, Sens. Actuators, B, 2016, 236, 233-240; (b) H. Xiao, Y. Zhang, W. Zhang, S. Li, J. Tan and Z. Han, Mater. Chem. Phys., 2017, 192, 268-273.

25 H.-W. Li, B. Wang, Y.-Q. Dang, L. Li and Y. Wu, Sens. Actuators, B, 2010, 148, 49-53.
26 (a) F. Jalilehvand, B. O. Leung, M. Izadifard and E. Damian, Inorg. Chem., 2006, 45, 66-73; (b) V. Mah and F. Jalilehvand, Chem. Res. Toxicol., 2010, 23, 1815-1823.

27 N. Dickerhof, J. F. Pearson, T. S. Hoskin, L. J. Berry, R. Turner, P. D. Sly and A. J. Kettle, Free Radicals Biol. Med., 2017, 113, 236-243.

28 C. B. Pocernich and D. A. Butterfield, Biochim. Biophys. Acta, 2012, 1822, 625-630.

29 M. Smeyne and R. J. Smeyne, Free Radicals Biol. Med., 2013, 62, 13-25.

30 S. Thiery, B. Heinrich, B. Donnio, C. Poriel and F. Camerel, J. Phys. Chem. C, 2015, 119, 10564-10575. 